\title{
IMPROVING THE TECHNICAL CHARACTERISTICS OF A DECONTAMINATION TANKER WITH THE HELP OF TRIZ
}

\author{
Obrad T. Čabarkapa ${ }^{a}$, Dušan S. Rajićb \\ University of Belgrade, Faculty of Technology and Metallurgy, \\ Innovation Center, Belgrade, Republic of Serbia \\ a e-mail: obrad.cabarkapa@gmail.com, \\ ORCID iD: Dhttp://orcid.org/0000-0002-3949-8227, \\ b e-mail: rajic.dusan1@gmail.com, \\ ORCID iD: (Dhttp://orcid.org/0000-0002-5226-4089
}

http://dx.doi.org/10.5937/vojtehg65-11002

FIELD: Chemical Technologies

ARTICLE TYPE: Professional Paper

ARTICLE LANGUAGE: English

\section{Summary:}

This paper explains the application of the TRIZ methodology (Theory of Solving Inventive Tasks) in the field of solving a technical problem in a decontamination tanker. TRIZ is one of the most suitable scientific and innovative methodologies for solving problems, based on a systematic and logical approach, developed as a result of studying a great number of patents. The correct use of a decontamination tanker identified a harmful function related to preparing the decontamination solution in the on-board reservoir itself, which disabled the supply of drinking water.

The function used to extend the use of decontamination tankers to delivery of drinking water was achieved using the Inventive Principles and Alshtuler's Contradiction Matrix, both known to be very efficient TRIZ methodology tools.

Key words: TRIZ methodology, harmful function, technical system, technical contradiction, contradiction matrix, inventive principles. 


\section{Introduction}

The decontamination tanker M-78 (ACD M-78) is a special vehicle adopted by the Serbian military (in CBRN service units) with its main application in radiological, chemical and biological decontamination of personnel and technical equipment (http://www.mycity-military.com, 2016). Apart from this application, it can also be used for personnel's hygiene, fire extinguishing, technical water supply, pumping water out flooded areas, soil chlorination, etc.

The tanker is served by a certain number of people- personnel. In order for the personnel to be able to carry out their tasks, the vehicle is equipped with the following: a device for personnel decontamination, device for decontamination of technical equipment, soil decontamination kit, reservoir filling kit, illumination kit, water pumping and fire extinguishing equipment, as well as equipment for heating the pump and hose instalations. The vehicle is given in Fig 1:

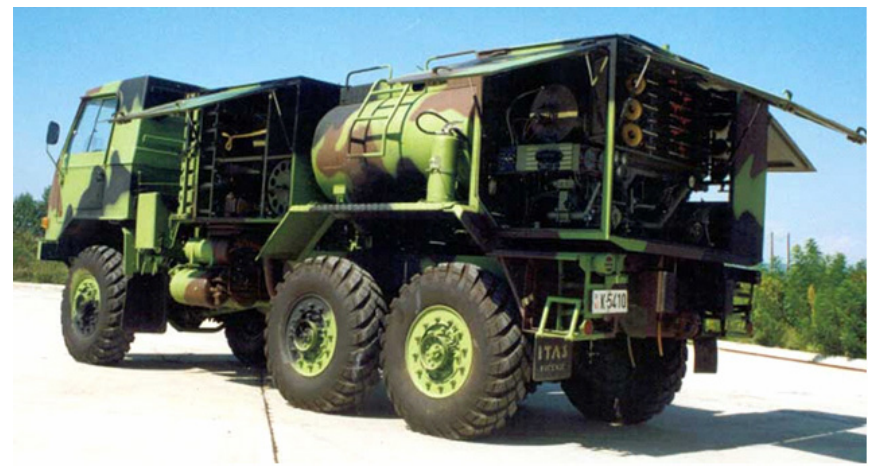

Figure 1 - Decontamination tanker M-78

Puс. 1 - Автоцистерна для деконтаминации M-78

Слика 1 - Аутомобил цистерна за деконтаминацију M-78

The decontamination accessories in the ACD M-78 are: shower collectors; shower packs; working hoses (20 and $10 \mathrm{~m}$ long); nozzles; hand sprayers; distribution hose (branches) and a collector.

The accessories help with the final and total radiological, chemical and biological decontamination of the personnel and technical means, with the option of radiological soil decontamination, object decontamination and fire extinguishing. Radiological decontamination refers to elimination of radioactive contaminants off a contaminated surface. A decontamination process strives towards a complete elimination of radioactive contaminants 
off a certain surface, and if this is not possible, then it is done to an extent that does not impose a danger in practice.

One of the Serbian army's missions is to support civilian government in fighting safety threats, as well as in case of natural disasters, industrial and other accidents and epidemics.

Over the recent years, Serbian army units have been engaged all over the country on numerous tasks- one of the most known ones to the public being the floods in Obrenovac. One of the main and most important tasks during these engagements is to enable water supply for the civilians ( for example, in Kraljevo after the 2010 earthquake, in Užice after the contamination of the accumulative lake Vrujci, in Obrenovac, Trstenik, Svilajnac and many other places around the Republic of Serbia after the floods that happened in May 2014).

During the realization of these tasks, it was noticed that there was a lack of the necessary number of water tankers in order to fulfill the population's needs.

The main technical problem that was noticed during the use of the ACD M-78 was the exclusive use of the tanker water for technical purposes (bathing, dish washing, clothes washing, etc.), and not for drinking. The main reason for this limited use of the tanker was that the substance solution for decontamination was prepared in the tanker's reservoir. Substances for decontamination are chemical compounds or mixtures which have the ability to react with poisonous chemical substances (PCS), to break them down or neutralize biological agents or help eliminate CBRN contaminants. Calcium hypochlorite and sodium hypochlorite are mostly used as decontamination substances.

There is a question of finding new ways to expand the technical possibilities of the ACD M-78, to use it not only for supplying technical water used for CBRN decontamination, as it has been the case until now, but also for supplying drinking water, which is a realistic need. The TRIZ methodology is suitable for solving the described problem (Rajić et al, 2006, pp.489-501), (Rajić, Čabarkapa, 2016, pp.701-704).

\section{Determining a harmful function of a decontamination tanker}

A decontamination tanker is seen as a technical system (TS) where there is an identified harmful function ( a technical problem) which refers to the preparation of the substance solution for decontamination in the reservoir - which disables supply of drinking water due to its contamination. 
Solving this problem would enable a new useful function in the tanker, which would increase the operating ability of the units and would contribute to the successful problem solving in case of natural disasters.

By applying TRIZ it is possible to solve the existing technical problem in the tanker i.e. discover how to eliminate the harmful function. The Inventive Principles and Contradiction Matrix have been proved to be the most often used tools in practice for solving the existing technical problems (Rajić et al, 2016, pp.95-150). A graphic display of the useful and harmful functions of the ACD M-78 is shown in Figure 2.

The useful tanker functions for decontamination come from its basic applications, and those are: radiological, chemical, and biological decontamination of personel and technical means, technical water supply, fire extinguishing, soil chlorination, pumping water out the flooded areas, etc.

By considering the need for the tanker to be used for drinking water supply, its harmful function was noticed- the inability to supply drinking water due to the fact that the preparation of the chemical solutions for decontamination was performed in the tanker itself.

Determining the harmful function imposed a question: What can be done so that the tanker, apart from its original application, could also be used for supplying drinking water?

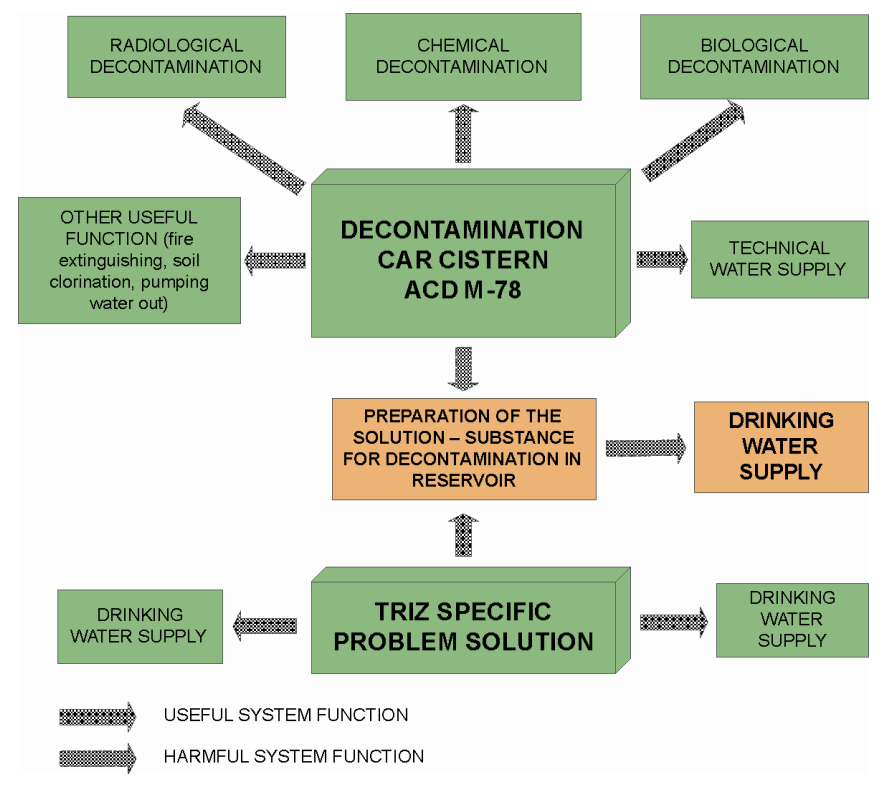

Figure 2 - Graphic representation of the useful and harmful functions in ACD M-78

Puc. 2 - Изображение полезных и вредных фуункций АЦД М-78

Слика 2 - Графички приказ корисних и штетних фуннкија АЦД М-78 
Solving this problem would establish another useful tanker function which would technically improve it - enabling the supply of drinking water, with the ultimate aim of increasing the units' efficiency level in delievering given tasks in emergency situations.

It is possible to solve the highlighted technical problem by applying the Inventive Principles and Contradiction Matrix, as the basic tools of the TRIZ methodology.

\section{Basic tools of the TRIZ methodology}

The Theory of Solving Inventive Tasks (TRIZ) is a well-known and often used methodology in the developed parts of the world. TRIZ as a method of solving technical contradictions was developed by a scientist and inventor Genrich Altshuller (15.10.1926 - 24.09.1998). The Theory of Solving Inventive Tasks is a methodology of solving problems in a systematical and logical way. This methodology is based on the axiom: »the evolution of all technical systems happens according to the objective laws». The application of the TRIZ methodology is a part of creative thinking (creatology), which should be the main tool on the route between a problem and its solution.

TRIZ is used worldwide. On a daily basis, it is used at 35 most prestigious universities and in more than 500 most powerful and leading world companies (Siemens, Boeing, NASA, Rolls Royce, Intel, XEROX, Motorola, HILTI, etc.).

This methodology leads an innovator towards the solution of a technical problem (new invention or approach or improved existing innovation or approach) in the shortest possible way and with the minimum use of resources. Compared to other methods of creatology which are used in the innovation work, TRIZ is considered to be the most efficient methodology based on the view that an invention is not a matter of inspiration- but on the contrary- an exact science. (Rajić et al, 2016, pp.81-349).

TRIZ uses the Inventive Principles (40 established principles, including segmentation, extraction, local quality, asymmetry, universality, consolidation, etc.) and the Contradiction Matrix as its basic tools. The Inventive Principles solve technical contradictions, while the Contradiction Matrix gives us a chance to choose the most effective Inventive Principle that needs to be applied in order for the problem to be solved. A contradiction is a problem that appears within a subsystem of a complex tecnical system ( cars, planes, cranes, etc.), as a consequence of the 
improvement of certain parameters of the complex technical system. For instance, it is necessary to lower a car's weight by replacing the shell material with a more modern material, without putting passengers' safety at risk.

There are certain parameters or characteristics for the description of every technical system. Some of them are: power, voltage, pressure, reliability, moving object's mass, adaptability, complexity of devices, etc., and they are contained in the Contradiction Matrix, dimensions 39X39.

The schematic representation of a part of the Contradiction Matrix is given in Table 1.

Table 1 - Contradiction Matrix

Таблица 1 - Матрица противоречий

Табела 1 - Матрица противречности

\begin{tabular}{|c|c|c|c|c|c|c|c|c|c|c|}
\hline \multirow{2}{*}{\multicolumn{3}{|c|}{ CHARACTERISTICS }} & \multicolumn{6}{|c|}{ Worsening Characteristics } & \multirow{2}{*}{\multicolumn{2}{|c|}{ PRINCIPLES }} \\
\hline & & & \multirow[t]{2}{*}{1} & \multirow[t]{2}{*}{2} & \multirow{2}{*}{\begin{tabular}{|c|}
$\mathbf{3}$ \\
15 \\
8,29 \\
34 \\
\end{tabular}} & \multirow[t]{2}{*}{4} & \multirow{2}{*}{$\begin{array}{c}5 \\
29 \\
17 \\
38 \\
34\end{array}$} & \multirow[t]{2}{*}{6} & & \\
\hline \multirow{9}{*}{ 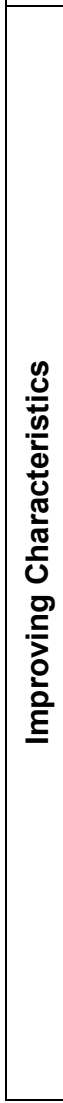 } & 1 & $\begin{array}{l}\text { Mobile object's } \\
\text { mass }\end{array}$ & & & & & & & Segmentation & 1 \\
\hline & 2 & $\begin{array}{l}\text { Stationed object's } \\
\text { mass }\end{array}$ & & & & $\begin{array}{c}10 \\
1, \\
29 \\
35\end{array}$ & & $\begin{array}{rr}35, & 30 \\
13, \quad 2\end{array}$ & Extraction & 2 \\
\hline & 3 & $\begin{array}{l}\text { Mobile object's } \\
\text { length }\end{array}$ & \begin{tabular}{|c}
8,15 \\
29 \\
34
\end{tabular} & & & & $\begin{array}{c}15 \\
17 \\
4 \\
\end{array}$ & & Local quality & 3 \\
\hline & 4 & $\begin{array}{l}\text { Stationed object's } \\
\text { length }\end{array}$ & & $\begin{array}{c}35 \\
28 \\
40 \\
29\end{array}$ & & & & $\begin{array}{c}17,7 \\
10,40\end{array}$ & Asymmetry & 4 \\
\hline & 5 & $\begin{array}{l}\text { Mobile object's } \\
\text { surface }\end{array}$ & $\begin{array}{r}2,17 \\
29,4\end{array}$ & & $\begin{array}{c}14,15 \\
18,4\end{array}$ & & & & Consolidation & 5 \\
\hline & 6 & Object's surface & & $\begin{array}{c}30,2 \\
14, \\
18\end{array}$ & & $\begin{array}{c}26 \\
7,9 \\
39\end{array}$ & & & Universality & 6 \\
\hline & 7 & $\begin{array}{l}\text { Mobile object's } \\
\text { volume }\end{array}$ & \begin{tabular}{|c|}
2,26 \\
29 \\
40
\end{tabular} & & \begin{tabular}{|c|}
1,7 \\
4,35
\end{tabular} & & $\begin{array}{c}1,7 \\
4,17\end{array}$ & & $\begin{array}{l}\text { Insertion } \\
\text { (matryoshka) }\end{array}$ & 7 \\
\hline & 8 & Object's volume & & $\begin{array}{c}35 \\
10 \\
19 \\
14\end{array}$ & 19,14 & $\begin{array}{l}35,8 \\
2,14\end{array}$ & & & Anti-weight & 8 \\
\hline & 9 & Speed & $\begin{array}{c}2,28 \\
13 \\
38\end{array}$ & & $\begin{array}{c}13,14 \\
8\end{array}$ & & $\begin{array}{c}29 \\
3034\end{array}$ & & $\begin{array}{l}\text { Preventive } \\
\text { counteracting }\end{array}$ & 9 \\
\hline
\end{tabular}


In the left column of the matrix there are the characteristics that need to be improved, while in the first row there are the characteristics that worsen as a consequence of the improving characteristics. In the Contradiction Matrix, in the intersection of the established characteristics, there are certain numbers that represent serial numbers of the principles suggested for application in order to solve the technical contradiction. Each of the offered principles suggests certain activities for possible solving of the described problem that is in the technical contradiction. The analysis of the offered activities leads to the conclusion on what needs to be done in order to solve the problem (Čabarkapa, 2010, pp.162-186).

\section{Solving the problem of preparing the substance solution for decontamination in the tanker}

To determine the exact technical contradiction, we would use the form for formulating technical contradictions (http://www.sigonline.rs, 2016), (Čabarkapa, 2010, pp.171-173), with the help of which we identify the characteristic that is about to be improved. This form comprises the following information: technical system's name, technical system's purpose, description of the technical system's function and determining the characteristic that needs to be improved or eliminated.

With the help of the form for formulating the technical contradiction, the characteristic that needs to be improved is determined and that is the characteristic that describes the problem best. That characteristic is «harmful inner factor of the object» placed under number 31 in the first column of the Contradiction Matrix. So, in order to solve the technical problem of preparing the solution material in the reservoir of the tanker itself, it is necessary to eliminate this characteristic. Then, the characteristics which will be worsened are being determined (they are in the first row of the Contradiction Matrix) as a consequence of the elimination of the harmful inner factors of the object. The following worsening characteristics are identified: 2 - 'stationed object's mass', 27 - 'reliability' and 36 - 'device complexity'. The schematic representation of the Contradiction Matrix's use for the described characteristics is given in Table 2. 
Table 2 - Representation of the use of the Contradiction Matrix

Таблица 2 - Применение матрицы противоречий

Табела 2 - Приказ коришћења матрице противречности

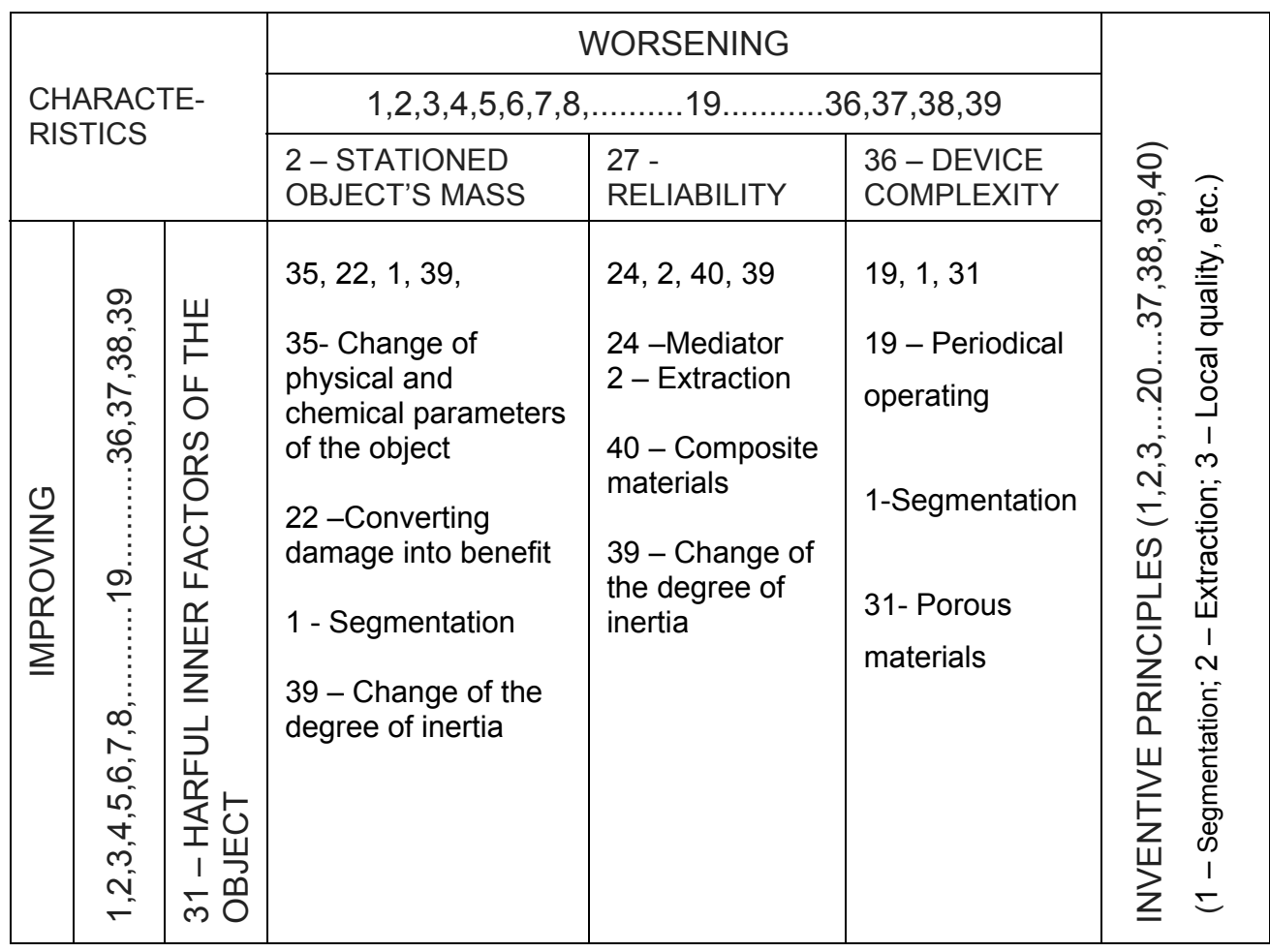

In the intersection of the rows (31 - improving characteristics) and columns (2, 27 and 36 -worsening characteristics), there are serial numbers of the Inventive Principles which should be considered when solving the technical contradiction. The names of the offered principles are given in the table. Each of the offered principles suggests taking certain actions in order to possibly solve the described problem which lies in the technical contradiction. A detailed analysis of the offered principles and activities which they suggest has shortlisted the following principles as the most suitable ones for the described case: 1 - 'Segmentation' and 24 'Mediator'.

The 'Segmentation' principle suggests undertaking the following activities:

$1 \mathrm{~A}$ - Divide the object into independent parts;

1B - Make the object modular (for easier assembly or dismantling),

$1 \mathrm{C}$ - Increase the degree of fragmentation of the object.

The 'Mediator' principle suggests undertaking the following activities: 
$24 \mathrm{~A}$ - Use an indirect object or a process, and

24B - Submerge one object into another (depending on which one is more suitable for carrying).

A detailed analysis of the offered activities brings us to the solution of the technical problem - it is necessary to introduce a new device which would solve the problem - not preparing the decontamination substance in the reservoir while still being able to perform decontamination successfully. It means that the solution of the problem consists of making a device outside the reservoir which would have a sufficient amount of concentrating solution for decontamination. The device would use a suitable regulating vent to release certain amounts of the solution for decontamination. It would be mixed with the water from the tanker reservoir, which would result in making the solution of the desired concentration outside the reservoir. The design of the device and regulation of its functioning would be an innovative solution of this problem. A basic block diagram of the useful functions of the ACD M-78 with the proposed device is given in Figure 3.

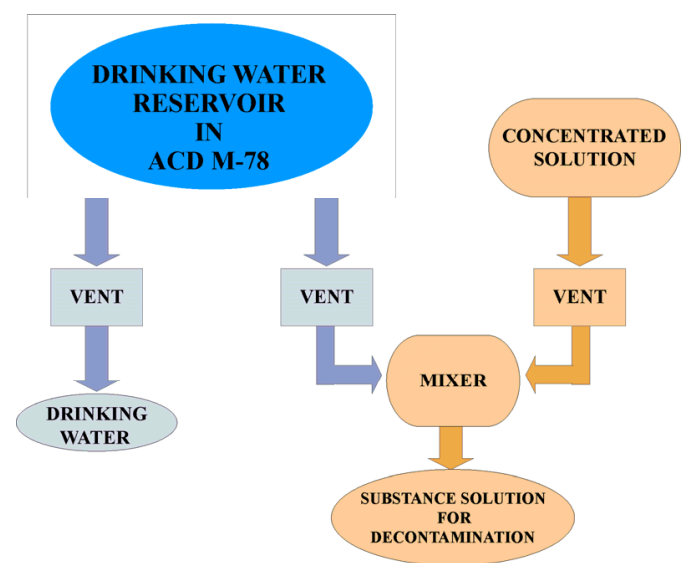

Figure 3-Graphic representation of the useful functions of the ACD M-78 Puс. 3 - Изображение полезных фрункий АЦД М-78

Слика 3 - Графички приказ корисних фрункција АЦД М-78

The installation of the suggested device, as well as establishing an additional installation (tubing) system from the device and the reservoir with the needed automatic regulating vents and pipes, asks for an engineer for its final construction solution, which needs to be protected according to a prescribed procedure (Čabarkapa et al, 2013a, pp.7-25), (Čabarkapa et al, 2013b, pp.146-161). 
In order to establish a new useful function of the ACD M-78 i.e. drinking water supply, it is necessary for the existing reservoir, previously used for the solution preparation, to be very well prepared (washed and disinfected) so that it could be used for transport of the drinking water.

Apart from described the technical solution to the tanker's problem, there also could have been other, similar, possibly better ones if we applied different TRIZ tools like the Substance-field Analysis and 76 Standards for Solving Innovative Problems, Application of Algorythms for Solving Inventive Tasks (ARIZ), Methods for Overcoming Psychological Inertia in Innovators, etc. about which there are detailed explainations in literature (Rajic, et al, 2016, pp.95-349).

\section{Conclusion}

The use of the decontamination tanker ACD M - 78 highlighted a technical problem. That is a harmful function of the system which manifests in inability to supply drinking water. The main cause of the harmful function is the preparation of the decontamination substance solution in the tanker reservoir itself.

TRIZ is a very suitable methodology for solving problems in complex technical systems. It is necessary to correctly formulate the technical contradiction i.e. to determine the technical characteristics of the system which need to be improved as well as the characteristics which will consequently worsen. In the ACD, the characteristic that was being improved (harmful inner factors of the object) was determined, as well as the characteristics that was being worsened (stationed object's mass, reliability and device complexity), as a consequence of the improving characteristic. By applying the basic TRIZ tools - the Inventive Principles and the Contradiction Matrix, the problem was solved: preparing the solution outside the reservoir with the help of an additional device which would contain the decontamination substance and which would be innovated and adapted for this purpose.

The application of the TRIZ methodology in solving the described technical problem offers possibilities to undertake certain innovative actions to enable drinking water supply with minimum financial investment. 


\section{References}

Čabarkapa, O., 2010. Zaštita poverljivih inovacija. Beograd: Redakcija „Vojna knjiga” (in Serbian).

Čabarkapa, O., Petrović, D., \& Bojović, M., 2013a. Prijava poverljivog patenta sa primerom sastavljanja, Vojnotehnički glasnik / Military Technical Courier, 61(4), pp.7-25. Available at: http://dx.doi.org/10.5937/vojtehg61-2048.

Čabarkapa, O., Petrović, D., \& Dunjić, M., 2013b. Uslovi patentibilnosti za zaštitu pronalazaka. Vojnotehnicki glasnik / Military Technical Courier, 61(1), pp.146-161. Available at: http://dx.doi.org/10.5937/vojtehg61-1595.

Rajić, D., \& Čabarkapa, O., 2016. Application of Innovation Standards in the Field of Weaponry and Military Equipment. In: $7^{\text {th }}$ International Scientific Conference on Defensive Technologies, OTEH 2016, Military Technical Institute, Belgrade, pp.701-704.

Rajić, D., Kamberović, Ž., \& Žakula, B., 2016. Kreativni inženjering. Beograd: Inovacioni Centar TMF (in Serbian).

Rajić, D., Žakula, B., \& Jovanović, V., 2006. Uticaj industrijske svojine na tehničko-tehnološki faktor odbrane. Vojnotehnički glasnik / Military Technical Courier, 54(4), pp.489-501.

http://dx.doi.org/10.5937/vojtehg0604489R.

http://www.sigonline.rs/files/File/knjige/uvodutriz.pdf. Accessed: 20 April 2016.

http://www.mycity-military.com/Vojske-sveta-baze-i-objekti/Naoruzanje-

Vojske-Srbije. Accessed: 20 April 2016.

\section{УЛУЧШЕНИЕ ТЕХНИЧЕСКИХ ХАРАКТЕРИСТИК \\ АВТОЦИСТЕРНЫ ДЛЯ ДЕКОНТАМИНАЦИИ, С ПОМОЩЬЮ ТРИЗ МЕТОДОЛОГИИ}

Обрад Т. Чабаркапа, Душан С. Раич

Университет в Белграде, Технологический и металлургический

факультет, Инновационый центр, г.Белград, Республика Сербия

ОБЛАСТЬ: химические технологии

ВИД СТАТЬИ: профессиональная статья

ЯЗЫК СТАТЬИ: английский

\section{Резюме:}

В данной статье представлено применение ТРИЗ (Теория решения изобретательских задач, в области решения технических проблем на автоцистерне для деконтоминации. ТРИЗ является одной из лучших научно-инновационных 
методологий по решению проблем, основанной на систематическом и логическом принципе, развитом на основании углубленного изучения большого количества патентов. При целевом применении автоцистерны для деконтоминации выявлена вредная функция, связанная с приготовлением деконтоминационного раствора в самом резервуаре, вследствие чего поставки питьевой воды в данных резервуарах исключаются. Благодаря применению ТРИЗ методологиии, а именно: инвентивных методов и матрицы Альштуллера, область использования автоцистерны для деконтоминации расширена за счет возможности поставки питьевой воды.

Ключевые слова: ТРИЗ методология, вредная функция, техническая система, технические противоречия, матрица противоречий, инвентивные методы.

\section{ПОБОЉШАЊЕ ТЕХНИЧКИХ КАРАКТЕРИСТИКА АУТОМОБИЛА} ЦИСТЕРНЕ ЗА ДЕКОНТАМИНАЦИЈУ ПОМОКУ ТРИЗ-А

Обрад Т. Чабаркапа, Душан С. Рајић

Универзитет у Београду, Технолошко-металуршки фракултет, Иновациони центар, Београд, Република Србија

ОБЛАСТ: хемијске технологије

ВРСТА ЧЛАНКА: стручни чланак

ЈЕЗИК ЧЛАНКА: енглесКИ

Сажетак:

У раду је приказана примена ТРИЗ методологије (Теорија решавања инвентивних задатака) у области решавања техничког проблема на аутомобилу цистерни за деконтаминацију. То је једна од најпогоднијих научно-иновационих методологија за решавање проблема, која почива на систематичном и логичком приступу, развијеном на основу студиозног изучавања великог броја патената. Наменском употребом аутомобила цистерне за деконтаминацију идентификована је штетна функција која се односи на припремање раствора за деконтаминацију у самом резервоару, чиме је онемогућен дотур воде за пиће.

Функција којом се проширује употреба цистерне за

деконтаминацију и за потребе доставе питке воде остварена је коришћењем инвентивних принципа и Алитулерове матрице противречности, као веома ефикасних алата ТРИЗ методологије.

Кључне речи: ТРИЗ методологија, итетна фрункција, технички систем, техничка противречност, матрица противречности, инвентивни принципи. 
Paper received on / Дата получения работы / Датум пријема чланка: 25.05.2016. Manuscript corrections submitted on / Дата получения исправленной версии работы / Датум достављања исправки рукописа: 20.02.2017.

Paper accepted for publishing on / Дата окончательного согласования работы / Датум коначног прихватања чланка за објављивање: 22.02.2017.

C 2017 The Authors. Published by Vojnotehnički glasnik / Military Technical Courier (www.vtg.mod.gov.rs, втг.мо.упр.срб). This article is an open access article distributed under the terms and conditions of the Creative Commons Attribution license (http://creativecommons.org/licenses/by/3.0/rs/).

() 2017 Авторы. Опубликовано в «Военно-технический вестник / Vojnotehnički glasnik / Military Technical Courier» (www.vtg.mod.gov.rs, втг.мо.упр.срб). Данная статья в открытом доступе и распространяется в соответствии с лицензией «Creative Commons» (http://creativecommons.org/licenses/by/3.0/rs/).

(c) 2017 Аутори. Објавио Војнотехнички гласник / Vojnotehnički glasnik / Military Technical Courier (www.vtg.mod.gov.rs, втг.мо.упр.срб). Ово је чланак отвореног приступа и дистрибуира се у складу са Creative Commons licencom (http://creativecommons.org/licenses/by/3.0/rs/). 